\title{
Grounded Theory methodological aspects in Brazilian nursing thesis
}

\author{
Teoria Fundamentada nos Dados: aspectos metodológicos em teses da enfermagem brasileira \\ Teoría Fundamentada en Datos: aspectos metodológicos en la tesis de enfermería brasileña
}

Nara Marilene Oliveira Girardon-Perlini'

ORCID: 0000-0002-3604-2507

Bruna Sodré Simon'

ORCID: 0000-0003-3855-1310

Maria Ribeiro Lacerda"

ORCID: 0000-0002-5035-0434

\section{ABSTRACT}

Objective: to analyze the application of methodological aspects of Grounded Theory in Brazilian nursing thesis. Methods: qualitative, descriptive study elaborated based on theses available in the CAPES Thesis and Dissertations Catalog, located with the search for the terms "Teoria Fundamentada nos Dados" OR "Grounded Theory", from 2013 to 2017. The data obtained were analyzed, considering the Grounded Theory methodological assumptions. Results: observance of Grounded Theory basic concepts and articulation with several theoretical frameworks in the conduct of the investigations are strengthening aspects of the method. However, dissent in the description of the operationalization of the stages and naming of the elaborated construct weaken the methodological quality. Final considerations: the methodological consistency provided by Grounded Theory has the potential to demonstrate the studies' rigor and reliability conducted and theories generated. It is necessary to deepen theoretical-conceptual studies to elucidate discrepancies in the applicability in nursing research.

'Universidade Federal de Santa Maria. Santa Maria, Rio Grande do Sul, Brazil.

"Universidade Federal do Paraná. Curitiba, Paraná, Brazil.

How to cite this article:

Girardon-Perlini NMO, Simon BS, Lacerda MR. Grounded Theory methodological aspects in Brazilian nursing thesis.

Rev Bras Enferm. 2020;73(6):e20190274. doi: http://dx.doi.org/10.1590/0034-7167-2019-0274 Descriptors: Grounded Theory; Qualitative Research; Nursing Research; Methodology; Nursing.

\section{RESUMO}

Objetivo: analisar a aplicação dos aspectos metodológicos da Teoria Fundamentada nos Dados em teses da área da enfermagem brasileira. Métodos: estudo qualitativo, descritivo, elaborado, a partir de teses disponíveis no Catálogo de Teses e Dissertações da CAPES, localizadas com a busca dos termos "Teoria Fundamentada nos Dados" OR "Grounded Theory", de 2013 a 2017. Os dados obtidos foram analisados, considerando-se os pressupostos metodológicos da Teoria Fundamentada nos Dados. Resultados: a observância dos conceitos básicos da Teoria Fundamentada nos Dados e a articulação com diversos referenciais teóricos na condução das investigações realizadas são aspectos fortalecedores do método. Contudo, o dissenso na descrição da operacionalização das etapas e a nomeação do construto elaborado fragilizam a qualidade metodológica. Considerações finais: a consistência metodológica proporcionada pela Teoria Fundamentada nos Dados apresenta potencial para evidenciar o rigor e a confiabilidade dos estudos conduzidos e das teorias geradas, sendo necessário aprofundar estudos de base teórico-conceitual para elucidar discrepâncias da aplicabilidade na pesquisa em enfermagem.

EDITOR IN CHIEF: Dulce Barbosa ASSOCIATE EDITOR: Mitzy Reichembach Enfermagem.

\section{RESUMEN}

Objetivo: analizar la aplicación de aspectos metodológicos de la teoría fundamentada en tesis en el campo de la enfermería brasileña. Métodos: estudio cualitativo, descriptivo, basado en las tesis disponibles en el Catálogo de Tesis y Disertaciones CAPES, ubicado con la búsqueda de los términos "Teoria Fundamentada nos Dados" OR "Teoría Fundamentada", de 2013 a 2017. Los datos obtenidos fueron analizados, considerando los supuestos metodológicos de teoría fundamentada en tesis. Resultados: la observancia de los conceptos básicos de teoría fundamentada en tesis y la articulación con varias referencias teóricas en la realización de las investigaciones realizadas son aspectos que fortalecen el método. Sin embargo, la disidencia en la descripción de la operacionalización de las etapas y la nominación del constructo construido socavan la calidad metodológica. Consideraciones finales: la consistencia metodológica proporcionada por el teoría fundamentada en tesis tiene el potencial de mostrar el rigor y la confiabilidad de los estudios realizados y las teorías generadas, lo que hace necesario profundizar los estudios teóricos y conceptuales para dilucidar las discrepancias en la aplicabilidad en la investigación de enfermería.

Descriptores: Teoría Fundamentada; Investigación Cualitativa; Investigación en Enfermería; Metodología; Enfermería. 


\section{INTRODUCTION}

Grounded Theory (GT) is a methodological framework that emerged in the 1960s, when Barney G. Glaser and Anselm L. Strauss developed systematic conceptions of qualitative data analysis. They used an inductive-deductive method to develop an explanatory theory of social phenomena, which was published in the book The Discovey of Grounded Theory: strategies for qualitative research, in $1967^{(1)}$.

GT's technical systematization and analysis procedures enable researchers to develop theories on the experiences of individuals, since it aims to achieve meaning, compatibility between theory and observation, capacity for generalization and reproducibility, precision, rigor, and verification ${ }^{(1-2)}$.

Over the six decades of application of the method, controversies surrounding the fundamental principles of the design of GT contributed to the emergence of methodological variations developed by authors who diverged to some extent from the original proposal ${ }^{(3-4)}$. Thus, the dominant configurations of GT, today, are defined as Glaserian, or traditional, or classical, which follow the initial model and are represented by Glaser; straussian or relativist, elaborated by Strauss and Corbin; and the constructivist, defended by Katy Charmaz ${ }^{(4)}$.

Although highlighting dissenting aspects, the three methodological currents of GT maintain some similarities with the original method, especially in relation to the sampling techniques, theoretical data saturation, constant comparative analysis, elaboration of memos and diagrams, theoretical sensitivity, and substantive theory ${ }^{(5-6)}$. As a difference between currents, the operationalization of data analysis and the proposition of a central category stands out $t^{(7)}$.

Considering the readings carried out, it could be seen that in nursing, specifically, GT has been increasingly constituting a powerful tool to conduct qualitative investigations. GT has contributed significantly to expand scientific productions, with regard to a broad thematic spectrum related to the daily complexities of professional practices, whether caring, managerial, educational or training.

It was also found that several studies have been published in recent years, in order to reflect on the characteristics that are similar and divergent among the different methodological currents of $\mathrm{GT}^{(7-9)}$. It was also identified researchers' interest in assessing quality and accuracy regarding the use of the method described in the original published articles ${ }^{(5-6,10)}$. In general, studies showed the growth in the use of GT in the investigations developed by nursing, the good methodological quality of publications, the method's contributions to the advances of the research, as well as the challenges resulting from the lack of consensus on some methodological elements to followed in the use of $\mathrm{GT}^{(4,11)}$.

Even so, it was noticed that the predominant analysis of the studies fell on documents published in the form of articles, which, in itself, represented limitations in the description of the processes and in the decisions adopted in the conduct of the research. In view of this, it is understood that the examination of research reports, especially of doctoral theses, offers rich, dense and rigorously described material, which makes it possible to apprehend and analyze the complexity of data collection and analysis procedures in GT. Therefore, it was decided to conduct the present study based on this material, seeking to answer the following question: how are the methodological aspects of GT presented in theses in the field of Brazilian nursing? The overview analysis of the method application in the theses makes it possible to identify the consensus and dissent that strengthen and/or weaken the reliability of the studies, pointing out aspects that need to be densified to consolidate the GT as a reference in nursing research.

\section{OBJECTIVE}

This study aims to analyze the application of methodological aspects of GT in data in theses in the field of Brazilian nursing.

\section{METHODS}

\section{Ethical aspects}

As this is an investigation into documents, there was no need for the study to be approved by the Human Research Ethics Committee. However, ethical and legal aspects regarding copyright were respected.

\section{Type of study}

This is a documentary ${ }^{(12)}$, descriptive, qualitative study, presented according to the Standards for Reporting Qualitative Research (SRQR) of the EQUATOR ${ }^{(13)}$ network.

\section{Study setting}

Catalog of Theses and Dissertations from the Coordination for the Improvement of Higher Education Personnel (CAPES Coordenação de Aperfeiçoamento do Pessoal do Ensino Superior).

\section{Methodological procedure}

For research development, 46 theses linked to Stricto Sensu Nursing Graduate Programs were analyzed, which used GT as a methodological framework.

\section{Data source}

To obtain the data, nursing theses available in the CAPES Thesis and Dissertations Catalog were analyzed, which were located through a search on the portal, using the terms "Teoria Fundamentada nos Dados" (Brazilian Portuguese) OR "Grounded Theory" and applying the filters "doctorate (thesis)" and "nursing" as an area of knowledge.

\section{Data collection and organization}

The time frame was from 2013 to 2017 , because with the implantation of the Sucupira Platform in 2013, the information from the Brazilian National Graduate System (Sistema Nacional de Pós-Graduação) is currently integrated, making it possible to access the research report in the database itself. The search was carried out in January and updated in June 2018. 
This process resulted in the identification of 53 theses reported on the CAPES portal. Of these, the report of 46 works was available for access, which comprised the corpus of analysis, and were consulted in full. Unavailable reports were also searched in the repository of the respective programs, and were not found.

In order to obtain the data of interest, a structured script was elaborated addressing the methodological elements recommended in an investigation that follows the GT precepts, which was filled with information extracted from the research report. The questions of interest referred to the identification of the work (title, year of defense, linked institution) and the scientific dimensions presented (research question, objectives, literature review, theoretical framework, theoretical current of the methodological framework, participants, sampling, hypotheses for theoretical sample conformation, tools for data collection, memos, diagrams, data saturation, data analysis process: type of coding, constant comparative analysis, theoretical sensitivity, central category, elaboration of theoretical model or theory, writing theory articulating the categories/concepts to the central category/concept).

\section{Data analysis}

Thesis reports were analyzed considering the assumptions of GT. For this, download of the reports available was performed online, for the organization of data related to the methodological dimension. Texts were read individually, extracting the information of interest and storing it in files in the program Word, separately, by thesis. Then, we sought to identify, in the material produced, the convergent and divergent aspects, condensing them to build a descriptive synthesis of each stage of the methodological aspects of the GT, considering the way the authors described it, item by item, for later reflection, with juxtaposition, on what the authors of the method mentioned.

The synthesis of the results obtained was presented in a descriptive manner and associated with a reflection, about the trends identified in the studies with regard to the application of the concepts and methodological procedures of the GT.

\section{RESULTS}

Regarding the year of defense, ten theses defended in 2013 were found; eleven, in 2014; five, in 2015; 13 in 2016 and seven in 2017. Among the 13 institutions that had Graduate Nursing Programs (GNP) linked to the works produced, Universidade Federal de Santa Catarina's GNP stood out, with the largest number of studies carried out addressing the GT framework (17), followed by the Universidade Federal do Rio de Janeiro and the Universidade de São Paulo, with eight studies each; Universidade Federal do Paraná and Minas Gerais, with four theses each; Universidade Federal de São Paulo and Pelotas, with three theses each; Universidade Federal do Rio Grande do Norte, with two and Universidade Federal do Rio Grande do Sul; Universidade Federal da Bahia, Fundação Rio Grande and Universidade Estadual de Maringá, with one thesis each.

The data related to the methodological dimensions of the studies were systematically organized in a chart that presents the analyzed characteristic and the main results found (Chart 1). The results were classified by grouping similar information in light of the GT fundamentals, regardless of the current adopted in the study.
Chart 1- Results of the analysis of the methodological characteristics of Grounded Theory in the Brazilian nursing theses from 2013-2017, Brazil, 2018

\begin{tabular}{|c|c|}
\hline $\begin{array}{l}\text { Methodological } \\
\text { characteristics }\end{array}$ & Main results obtained \\
\hline Research question & $\begin{array}{l}\text { Experiences (16), meanings (15), others (14), } \\
\text { do not present (1). }\end{array}$ \\
\hline Objective & $\begin{array}{l}\text { To understand (27), to analyze (6), to develop } \\
\text { theoretical model/theory (5), to identify (3), to } \\
\text { interpret (2), to evaluate (1), to describe (1), to } \\
\text { explore (1). }\end{array}$ \\
\hline Literature review & Yes (46) \\
\hline $\begin{array}{l}\text { Theoretical } \\
\text { framework }\end{array}$ & $\begin{array}{l}\text { Symbolic Interactionism (21), complexity (7), } \\
\text { Grounded Theory (7), mixed methods (4), } \\
\text { Virginia Henderson (1), Attachment Theory } \\
\text { (1), Transition Theory (1), Lean Philosophy (1), } \\
\text { Systemic Theory (1). }\end{array}$ \\
\hline $\begin{array}{l}\text { Generation of } \\
\text { hypotheses for } \\
\text { shaping the } \\
\text { theoretical sample }\end{array}$ & $\begin{array}{l}\text { Hypothesis developed in the analysis process } \\
\text { using the constant comparative method } \\
\text { (24); hypothesis elaborated by theoretical } \\
\text { assumption (13); does not present a } \\
\text { hypothesis (9). }\end{array}$ \\
\hline Sample groups & Yes (37); no (9). \\
\hline Data collection tool & $\begin{array}{l}\text { Interview (deep, intensive or semi-structured) } \\
\text { (46); observation (12); field diary (3); scales (4); } \\
\text { others (2). }\end{array}$ \\
\hline $\begin{array}{l}\text { Coding and Constant } \\
\text { comparative analysis }\end{array}$ & $\begin{array}{l}\text { Open, axial and selective - Strauss and } \\
\text { Corbin (35); initial and focused - Charmaz (8); } \\
\text { selective and theoretical open - Glaser (3). }\end{array}$ \\
\hline Memos & $\begin{array}{l}\text { They describe the elaboration and present an } \\
\text { example (31); do not have (15). }\end{array}$ \\
\hline Diagrams & They present diagrams (43); do not have (3). \\
\hline Data saturation & Referred (38); not mentioned (8). \\
\hline Central category & $\begin{array}{l}\text { Central category (19); central phenomenon } \\
\text { (18); others (3); does not refer (6). }\end{array}$ \\
\hline Validation & $\begin{array}{l}\text { With validation (target population, experts in the } \\
\text { method or theme) (27); without validation (19). }\end{array}$ \\
\hline
\end{tabular}

\section{DISCUSSION}

Publicizing online of the theses and dissertations produced by the doctoral and master's programs in the Catalog has been a requirement of CAPES since 1996, for knowledge dissemination and for program monitoring and evaluation, being currently synchronized to information Sucupira Platform. Failure to locate seven theses in the Catalog may be related to the protection of copyright as a strategy to preserve the originality of the work and meet the criteria of publicity required by the journals, which consider the existence of the version of the report available electronically to be published ${ }^{(14)}$.

Location and number of theses linked by the Programs showed that, although there were researchers who used the GT method in different Brazilian regions, the concentration of studies was in the central-south region, a characteristic that refers to the history of first Graduate Nursing courses in Brazil, created in these regions ${ }^{(15)}$.

As for the methodological aspects contemplated in the studies, the elaborated analysis considered, as a starting point, the premise that the description of the methodological steps of an investigation are predictive elements of scientific rigor and 
quality of work. Therefore, considering that building a research begins with the definition of research question, it was realized that the studies carried out were consistent with the principles of GT, as they referred to phenomena related to experiences and meanings attributed to events in the research. human life and doing nursing and being a nurse. GT is interested in people's lives, their behaviors and their interactions, seeking to understand the meaning behind human behavior and generate a theory about a given basic psychosocial or social process ${ }^{(16)}$.

The objectives outlined were congruent to the questions asked and the verbs used were mostly comprehensible or interpretive and some were exploratory-descriptive, which, in a way, weakened the use of the method, which is explanatory. There are objectives that explicitly propose the elaboration of theoretical models, or substantive theories, or explanatory models, this being the main purpose of a GT.

Although all the analyzed papers presented a chapter destined to a literature review on the studied subject, following the trend of the research developed in Graduate Programs, this dimension presents itself as a controversial aspect in the construction of an investigation, under GT precepts. Original texts argue that researchers should enter the research field, with a minimum of prior knowledge about the topic to be studied, as a requirement not to elaborate hypotheses that may influence the look at the data, since these hypotheses would be verified in the course of empirical research ${ }^{(2)}$.

For this reason, researchers should not consider theories that already exist, based exclusively on the data collected and on what they reveal about the investigated object. Existing theories would be taken into account in the more advanced stages of data analysis. In this sense, it was noticed that the theses followed a pattern of elaboration and presented a chapter of literature review consistent and comprehensive, which, in most cases, is built, based on the guiding characteristics of the reports requested by the GNP, however the moment when they were built was not explained in the works.

However, it should be noted that this aspect does not find consensus among GT scholars, including, with divergence between the authors of the different currents. This orientation is described in some critical texts as a "misunderstanding of interpretation", a "misunderstanding" of the original work, a "myth based on false premises" and a "naive stance", since researchers do not enter in the research process with a "clean and empty mind"(17). Considering that the methodological choices related to data collection techniques and procedures depend on the knowledge on the subject and that this allows researchers to be aware of what happens in the research setting, it seems important not to ignore the existing literature on the topic without, however, to claim to prove or refute preconceived hypotheses. Keeping an open mind makes it possible to apprehend new perspectives and different nuances about the object studied.

It was found that the tendency of Brazilian researchers is to adopt a theoretical framework to illuminate the data analysis, with Herbert Blumer Symbolic Interactionism and Edgar Morin's Theory of Complexity being the most used. As the GT has roots in Symbolic Interactionism and proposes to understand reality, from the knowledge of the perception or the meaning that $a$ certain context or basic social process has for people, the use of this framework allows the understanding of phenomena related to the interaction that intersects with the different scenarios of nursing praxis ${ }^{(11)}$. Complexity Theory has been a useful reference for studies of processes that occur in the daily work of health institutions, as knowledge and human relations do not follow a linear thought, being complex and constantly under construction, and that, for this reason, need the multiplicity of different subjects to be learned ${ }^{(18)}$.

It was observed that, in some studies, the conformation of the theoretical sample occurred with the generation of hypotheses, constituted in the development of the constant comparative method, as predicted by the initial authors of GT. Others, however, described hypotheses, which were established previously, at the beginning of the data collection process, and are then characterized as defined by theoretical assumptions. There were studies, however, that did not mention the constitution of sample groups or did not inform how they were organized.

The hypotheses listed, based on the movement of coming and going in the data, in a process of constant comparison, converge with the inductive-deductive aspect inherent to the method, since the theoretical sampling is defined, in the first instance, inductively, in the sense to seek participants who can better present their experiences in relation to the phenomenon studied. The construction of possibilities to expand the understanding of the investigated object constitutes the criterion of variability, which leads to the promotion of an ideal context, which can include all possible dimensions of the phenomenon, allowing the consolidation of the theory ${ }^{(19)}$.

Researchers can formulate hypotheses based on the data, with the cyclical process of collecting, coding, analyzing and writing memos, that will allow to apprehend different perspectives of the studied phenomenon and will serve as a guide to direct the new components of the sample, configuring them whether as the deductive aspect. This process was useful to define the study participants and to organize the composition of the different sample groups.

The first sample group is defined by researchers who, through the initial analysis and integration of the coded data, will formulate hypotheses that will guide the decision of which questions need to be answered, which codes need to be densified, expanded or saturated, where to collect new data and with whom, conforming new sample groups ${ }^{(19)}$. In the induction-deduction (or hypothesis formulation) process, researchers, in addition to guiding their data collection, develop insights by which they can change the questions to be asked to new participants ${ }^{(10)}$.

In GT, induction occurs since its initial process, when a population is sought that can help to discover the development strategies for the situations (phenomenon) studied ${ }^{(2)}$. Deduction occurs by creating the codes, in which researchers need to understand them as concepts, which are based on the data, allowing the construction of the variability of the groups to be researched ${ }^{(10,19)}$. Therefore, verifying hypotheses deduced or preconceiveds, based on the existing literature, does not correspond to the methodological assumptions of GT, which argues that it is necessary to be open to new and unforeseen discoveries ${ }^{(10,19)}$. In this perspective, could be considered that the observed in some 
studies of constitution of elaborated sample groups, a priori, as well as the non-conformation, represented a weakness in the use of the method.

The tools identified for data collection was the interview method used in all works, followed by of observation, focus groups and documentary sources, such as patient records or other documents. Use of different tools for obtaining data is allowed, since GT presents itself as a flexible method. Interview use as preferred technique of choice has also been found in other studies $(4,18,20)$.

Considering that GT aims to generate a substantive theory that explains, conceptually, people's experiences and the meanings they attribute to these experiences, by means of understanding human behavior, it is worth mentioning that this claim addresses an aspect which involves subjectivities, making it unquantifiable, possible to reach, above all, by conducting interviews, which, for interpretation, require from researchers a constant inductiondeduction process ${ }^{(18-19)}$.

As a methodological framework with positivist roots, GT allows analyzing any type of data, since 'everything is data ${ }^{\prime(1)}$, favoring the development of mixed studies, which complementarily use quantitative and qualitative data, making use of, for this, scales, as was found in analyzed theses. Although the interview and the observation showed the property in the use of the data collection methods, it was possible to identify the incipients in the appropriation of certain concepts that make up GT, such as a study that mentions memos as tools of data collection. Although conceptual misconceptions are in the minority, they signal the need to maintain vigilance in how to describe them.

Data coding and constant comparative analysis are common steps adopted by all GT currents for data analysis, however there are differences in how this step should be structured and carried out. It was identified that the theses used the coding proposed by Glaser (open, selective and theoretical), Strauss and Corbin (open, axial and selective) and by Charmaz (initial and focused). However, it was observed that some theses reported being electing, as a framework, a given current, although this was not the same followed in the coding performed. Given this observation, it is questioned to what extent the results can be influenced by the use of different currents in the study? How can the analysis technique have an impact on the process of obtaining and analyzing data and on the construction of emerging theory? Could this dissonance be considered a weakness in studies? With regard to theoretical coding, the one with the highest level of abstraction, it is clear that this stage is incipient in the works, as it does not provide a description of how it was carried out.

For data organization and coding, it was observed that the most recent theses trend was to use software to assist in this process, with NVivo and Atlas Ti being the most cited. Although there is no consensus among the authors of GT regarding the use of technological resources - Glaser discourages, while Strauss and Corbin and Charmaz consider it useful - some researchers have used them and present prints of parts of the coding step to illustrate the procedure ${ }^{(21)}$. Depending on the quality of the image, these are barely legible, not contributing to the apprehension of information and learning by other researchers.

Performing theoretical or selective coding points to the choice of researchers for a given current, but the use of it in a reflexive way will show the theoretical sensitivity, the proper use of the circularity of the data and the connections that were made with and for the interpretation of the data. With this, the construction of the analysis process is raised to a conceptual level, which is the essence of GT and, thus, a level is reached in which the properties and dimensions of the phenomenon are explicit, transcending the description of behavior human.

The memos, elaborated since the data coding phase, consist of writing ideas about the codes and their relations, reflections on what is happening with the data and other aspects necessary for the collection and analysis. Ignoring them can weaken the construction of the theory. However, it was found, through the analysis of the theses, that although the elaboration of memos is not always mentioned, they were present and exemplified. Memos can arise from insigths, at any time, from immersion in the substantive area, as it is part of the abstraction process, requiring researchers to be aware of the need to register them immediately, under the risk of not being able to resume them whenever their wish.

By using this resource, researchers make it possible for each question and reflection elaborated, to deepen the understanding and explanation of the studied phenomenon. Thus, the memos clearly show the gaps in the existing analyzes and the possible new directions related to the emerging theory, giving scope and density to compose the development of the constant comparative method, as a tool that indicates possibilities and guidelines to assist in the elaboration of concepts and theory writing ${ }^{(2,22)}$.

The diagrams presented in the theses proved to be diverse, as there were works in which they were as a graphical representation originated from the coding or categorization of data and others were characterized by explaining the integration between the concepts. Diagrams are representations that are at the discretion of researchers' creativity and assist in visualizing the interrelationship between concepts and between these and the central category $^{(22)}$. The presence of this resource points to the level of reflection used in the analysis of the data for the construction of the construct. The more explicit and elucidative the connection diagrams are, among the different concepts that emerged, the more strongly indicates that the dimensions and properties of the phenomenon are present.

Data saturation, referred to in the studies as the parameter to end the process of collecting and constituting sample groups, due to the non-emergence of new data that contribute to the densification of the dimensions and properties of the elaborated categories, is a concept related to sampling theoretical ${ }^{(1)}$. The reach of saturation is characterized, not by the number of study participants, but as an indication that the incidents emerging from the data collection added (or not) to the development of the categories, signaling the moment of the research in which all categories were consistent in its completeness in relation to the studied phenomenon. It was also observed that the number of study participants was quite diverse, as well as the number of sample groups constituted (generally, three), which converged with the one proposed by the method and strengthened it. However, it is noteworthy that the non-composition of sample groups, the failure to mention the number of participants in each group and the hypotheses that contributed to the selection, when it involved people, represented an identified methodological gap. 
Central category elaboration, with the property of giving meaning, articulating and integrating all categories referring to the studied phenomenon was presented in most of the theses. However, this name was not used unanimously by researchers, although it was based on the same elaboration principle. On the other hand, it was found that there were works that referred to the elaboration of a central variable, the central phenomenon, the central construct or the central concept. Studies that did not mention this concept were also identified in the methodology chapter, did not present a category that would unify and integrate the others, as well as not showing a representative diagram of this process.

In the perspective of the Glasserian current, the central category emerges in the course of the categorization process, the result of the delimitation of theory and categories. This category integrates all the others and is broad and abstract enough to include and express all of them, constituting substantive concepts that enable the construction of the theory ${ }^{(19)}$. In the Straussian proposition, the establishment of the central phenomenon or category of research is supported by the paradigmatic model that assists in the analysis process ${ }^{(7,16)}$. In constructivism, the identification of the central category is related to the concepts that emerge more frequently in the analysis, representing the most analytically powerful organizing concept ${ }^{(7,23)}$.

In summary, it can be said that the proposition of a central category is the result of researchers' capacity for abstraction, by combining theoretical sensitivity with the inductive-deductive process, to refine, densify and reduce the categories and reveal the discovery of underlying uniformities in the original set of categories or their properties. In this sense, a central variable is a substantive category that accounts for the greatest variation in resolving the main concern of the participants. What is produced explains the action, that is, how people work to solve the basic social problem, corresponding to a pattern of behavior ${ }^{(19)}$.

In turn, the central category explains most of the variation around the problem, which is the focus of the study. Its main function is to integrate the theory and make it dense and saturated, constituting a pattern that proves to be related to other variables $^{(19)}$. In this way, the central category becomes the "lens" through which researchers looks at his data to generate the theory, resulting from his sensitivity to find, empirically, the concept that best summarizes and explains the essence of what is happening in the data ${ }^{(19)}$. Sometimes, in the theses analyzed, the way researchers name the central category and describe it, establishing the relationship and articulation with the other categories, which are also named, creates difficulties for the reader to understand how, in fact, this process occurs. This may be related to the need for understanding and appropriation between the abstraction of categorization and concepts, which should be used in the preparation of the text.

GT elaboration, which explains the phenomenon, representing it graphically, as a result of the abstraction and mode of integration and interrelation of the central category and the other concepts, is expected. Although GT makes this theoretical construction possible, the authors do not define it as a mandatory condition, since the method, being flexible and depending on researchers' theoretical skills and sensitivity, can be concluded without achieving this purpose.
In the theses analysis, it was found that not all the works developed resulted in a substantive theory, but those that did, presented the wording of the theory and the representative diagram, which reveals the appropriation of the method in its completeness and strengthens the use of GT as a methodological framework capable of generating knowledge.

For the elaboration of the theoretical model or the theory, writing is a crucial aspect for the construction of this knowledge, as it is necessary that the theory is explanatory and that it indicates its connections. In this particular issue, writing the theory expresses researchers' theoretical sensitivity and appropriation that they make, theoretically, of the object under study. It is the moment when the conceptual elevation is more present, as it shows how the theoretical or selective categorization occurred and how the central category anchored this construction.

However, the nomination of the theoretical product constructed in theses shows that there is no consensus on this dimension of GT. In the studies analyzed, the development of theoretical models, models (paradigmatic, interpretive or explanatory), substantive theories, theories, phenomenon, care model, conceptual category, was identified among the most cited names, or did not mention anything in this sense. Discussions are also found in the literature that deal with the differences between theory, theoretical structure and conceptual models, since what one author calls theory, another may call the conceptual model(24).

Therefore, the conceptual model refers to a group of concepts or ideas that are related, but in which the relationship is not explicit. Models, on the other hand, speak of an abstract perspective or structure that represents reality and use concepts to symbolize meanings, but do not represent the real world. They are more abstract, with defined concepts, less specifically than theories, and do not explain how or why the phenomena occur ${ }^{(24)}$. Theory is a highly complex term, with arbitrary meanings that, depending on the author's position, can propose ideas or intuitions that need to be tested ${ }^{(24)}$. Although there is a lack of consensus on what a theory is, there is an agreement between disciplines that theory refers to a set of defined and interrelated concepts and a network of relational statements or systematic and logical propositions. The difference between theory and models is related to the level of abstraction, degree of explanation and level of development of the construct. All theories are models, because they claim to represent some aspect of reality, however models are not necessarily a theory. Usually, they precede and coexist with the ${ }^{(24)}$ theory.

In view of the diversity of nomenclatures identified, the difficulty encountered by Brazilian researchers is clear to understand what would be more appropriate in the applicability of GT, or in the appropriate way of using the methodology, explaining that the uncertainties, the imprecision, the dubious interpretations and the lack of property contributes to questions about the scientific validity of the work performed. Furthermore, it can be inferred that the denomination used to define the product of the applicability of GT expresses the partial use of a certain methodological theoretical misunderstanding, incurring a theoretical construction, with little density and robustness and with partial understanding of the studied phenomenon.

Regarding the validation of the product elaborated in the theses, regardless of the nomination used, it was found that, 
among those who did, the validation was performed by the target population of the study, by experts in the method or in the theme, with the participation of more than one category of validators in some studies. As a strategy for the validation of theoretical constructs arising from the GT, conversation circles are presented as viable alternatives, as they enable collective and cooperative discussion of the results of the investigations, privileging methodological assumptions and scientific rigor ${ }^{(25)}$.

\section{Study limitations}

As study limitations, possible gaps stand out in relation to the data collection tool developed according to researchers' criteria, and also, the gaps inherent in the interpretive subjectivities printed during the analytical process.

\section{Contributions to nursing}

The present study contributes to the discussions related to the quality of the productions developed with the GT and constitutes a potential resource to stimulate reflection and theoretical deepening in the applicability of the method, which can assist in the understanding and operationalization of the concepts that integrate it.

\section{FINAL CONSIDERATIONS}

This study on the use of GT in the theses produced in the Brazilian nursing area proved to be relevant in the field of knowledge production, as it points to the aspects that can strengthen its applicability. Even though it can be said that there was coherence between the theoretical assumptions of the methodological framework and the research conducted in Brazilian nursing, gaps were highlighted that need to be deepened and strengthened, especially with regard to the description and justifications for the decisions taken conducting studies. These aspects are important for the evolution of the method, for building consensus and for guaranteeing the rigor, quality and reliability of the studies produced with this methodological framework.

In this sense, it is understood that, among the aspects that need to be densified in the use and methodological description of GT are appropriation of the concepts that guide the collection process, data analysis and the theoretical product generated, so that they are not described in a confused, contradictory way or not listed; selection/definition of sample groups (need to make explicit the inductive-deductive aspects that contribute to the formulation of hypotheses); use of memos and diagrams (which should be mirrored in the theory constructed in its connections, dimensions and properties); and presentation of the theory constructed with an explanation based on the theoretical or selective categorization and with its respective graphic representation.

GT represents an important tool for conducting research in nursing, as it makes it possible to understand people's behavior, considering experiences as broad social events, which, in order to be learned, need to examine the different perspectives of the same phenomenon and the context in which occurs. This characteristic denotes the relevance of this framework and the need to constantly reflect and analyze what we are researching, how we are researching and how we are presenting the knowledge produced, since the process of reflection does not end.

\section{FUNDING}

This study was supported by CAPES - Brazilian National Postdoctoral Program (PNPD - Programa Nacional de Pós-Graduação).

\section{REFERENCES}

1. Glaser B, Strauss A. The Discovery of Grounded Theory: strategies for qualitative research. Chicago: Aldine; 1967. 271p.

2. Glaser B. The Grounded Theory Perspective: its origin and growth. Mill Valley: Sociology Press; 2016. 119p.

3. Kenny M, Fourie R. Tracing the history of grounded theory methodology: from formation to fragmentation. Qualit Rep [Internet]. 2014[cited 2018 Aug 10];19(52):1-9. Available from: http://www.nova.edu/ssss/QR/QR19/kenny103.pdf

4. Santos JLG, Erdmann AL, Sousa FGM, Lanzoni GMM, Melo ALSF, Leite JL. Methodological perspectives in the use of grounded theory in nursing and health research. Esc Anna Nery [Internet]. 2016[cited 2018 Aug 10];20(3). Available from: http://www.scielo.br/pdf/ean/v20n3/ en_1414-8145-ean-20-03-20160056.pdf

5. Barreto MS, Garcia-Vivar C, Marcon SS. Methodological quality of grounded theory research with families living with chronic illness. Int J Africa Nurs Sci [Internet]. 2018[cited 2018 Aug 10];8:14-22. Available from: https://www.sciencedirect.com/science/article/pii/ S2214139117300999

6. Koerich C, Copelli FHS, Lanzoni GMM, Magalhães ALP, Erdmann AL. Grounded theory: evidencing divergences and contributions for nursing research. Rev Min Enferm [Internet]. 2018[cited2018 Sept30];22. Available from: http://www.reme.org.br/artigo/detalhes/1222

7. Santos JLG, Cunha K, Adamy EK, Backes MTS, Leite JL, Sousa FGM. Data analysis: comparison between the different methodological perspectives of the grounded theory. Rev Esc Enferm USP [Internet]. 2018[cited 2018 Sep 30];52. Available from: http://www.scielo.br/pdf/ reeusp/v52/en_0080-6234-reeusp-S1980-220X2017021803303.pdf

8. Gomes IM, Hermann AP, Wolff LDG, Peres AM, Lacerda MR. Grounded theory in nursing: an integrative review. Rev Enferm UFPE [Internet]. 2015[cited 2018 Sep 30];9(Suppl.1):466-74. Available from: https://periodicos.ufpe.br/revistas/revistaenfermagem/article/view/10360/11084

9. Cuesta-Benjumea C, Arredondo-González CP. Analizar cualitativamente: de las consideraciones generals al pensamiento reflexivo. Index Enferm [Internet]. 2015[cited 2018 Sep 30];24(3):154-58. Available from: http://scielo.isciii.es/scielo.php?script=sci_arttext\&pid $=$ S1132-12962015000200008 
10. Silva GWS, Enders BC, Sousa FGM, Sena JF, Santos RC, Silva AB. Grounded theory in theses and dissertations of Brazilian nursing. Texto Contexto Enferm [Internet]. 2018[cited 2018 Nov 28];27(4). Available from: http://www.scielo.br/pdf/tce/v27n4/en_0104-0707-tce-2704-e3870017.pdf

11. Silva MM, Moreira MC, Leite JL, Stipp MAC. A teoria fundamentada nos dados nos estudos de pós-graduação stricto sensu da enfermagem brasileira. Rev Eletrôn Enferm [Internet]. 2011 [cited 2018 Sep 30];13(4):671-9. Available from: http://www.fen.ufg.br/revista/v13/n4/pdf/ v13n4a11.pdf

12. Kripka R, Scheller M, Bonotto DL. Pesquisa documental: considerações sobre conceitos e características na pesquisa qualitativa. Atas Investig Qualit Saúde [Internet]. 2015 [cited 2018 Sep 30];2:243-7. Available from: http://www.proceedings.ciaiq.org/index.php/ciaiq2015/ article/view/252/248

13. O'Brien BC, Harris IB, Beckman TJ, Reed DA, Cook DA. Standards for Reporting Qualitative Research: a synthesis of recommendations. Acad Med [Internet]. 2014 [cited 2019 Mar 14];89(9). Available from: https://journals.Iww.com/academicmedicine/fulltext/2014/09000/ Standards_for_Reporting_Qualitative_Research_A.21.aspx

14. Equipe Editorial da Scientia Medica. O que compromete o ineditismo de um artigo (editorial). Sci med [Internet]. 2013 [cited 2018 Sep 30];23(4):211-2. Available from: http://revistaseletronicas.pucrs.br/ojs/index.php/scientiamedica/article/ view/1980-6108.2013.4.16588/13219

15. Scochi CGS, Munari, DB, Gelbcke FL, Erdmann AL, Gutiérrez MGR, Rodrigues RAP. Pós-graduação stricto sensu em enfermagem no Brasil: avanços e perspectivas. Rev Bras Enferm [Internet]. 2013 [cited 2018 Sep 30];66(esp):80-9. Available from: http://www.scielo.br/pdf/reben/ v66nspe/v66nspea11.pdf

16. Corbin J, Strauss A. Basics of qualitative research: techniques and procedures for developing ground theory. Los Angeles: Sage Publications; 2015. 456p.

17. Leite F. Raciocínio e procedimentos da grounded theory construtivista. Questões Transversais Rev Epistemol Comun [Internet]. 2015[cited 2018 Sep 30];3(6):76-85. Available from: http://revistas.unisinos.br/index.php/questoes/article/view/11310/PDF

18. Lacerda MR, Hermann AP, Balduíno AFA, Gomes IM, Nascimento JD. Teoria Fundamentada nos Dados. In: Lacerda MR, Costenaro RGS (Org). Metodologias da pesquisa para enfermagem e saúde: da teoria à prática. Porto Alegre: Moriá, 2015. 512p.

19. Glaser BG. Choosing classic Grounded Theory: a Grounded Theory reader of expert advice. Mill Valley: Sociology Press; 2014. 439p.

20. Gomes JS, Girardon-Perlini NMO, Coppetti LC, Dalmolin A. Grounded theory as a methodological reference for research with families in Brazilian nursing. Ciênc Cuid Saúde [Internet]. 2017 [cited 2018 Sep 30];16(4):1-9. Available from: http://periodicos.uem.br/ojs/index.php/ CiencCuidSaude/article/view/39467/pdf_1

21. Nascimento JD, Gomes IM, Lacerda MR, Camargo TB, Utzumi FC, Bernardino E. Uso del software NVivo ${ }^{\circledast}$ en una investigación con com teoría fundamentada. Index Enferm Dig [Internet]. 2016 [cited 2018 Nov 28];25;263-7. Available from: http://scielo.isciii.es/scielo.php?script=sci_ar ttext\&pid=S1132-12962016000300009

22. Andrews T, Mariano GJS, Santos JLG, Koerber-Timmons K, Silva FH. The methodology of classic grounded theory: considerations on its application in nursing research. Texto Contexto Enferm [Internet].2017 [cited 2018 Oct 03];26(4). Available from: http://www.scielo.br/pdf/ tce/v26n4/en_0104-0707-tce-26-04-e1560017.pdf

23. Charmaz KA. Construção da Teoria Fundamentada: guia prático para análise quantitativa. Porto Alegre: Artmed; 2009. 272p.

24. Christensen PJ, Kenney JW. Nursing Process: application of conceptual models. St. Louis: Mosby; 1995. 335p.

25. Adamy EK, Zocche DAA, Vendruscolo C, Santos JLG, Almeida MA. Validação na teoria fundamentada nos dados: rodas de conversa como estratégia metodológica. Rev Bras Enferm [Internet]. 2018 [cited 2019 Dec 24];71(6). Available from: http://www.scielo.br/pdf/reben/v71n6/ pt_0034-7167-reben-71-06-3121.pdf 